\title{
An assessment of the water quality of the Isinuka springs in the Transkei region of the Eastern Cape, Republic of South Africa
}

\author{
JA Faniran ${ }^{1 *}$, FS Ngceba ${ }^{1}$, RB Bhat ${ }^{2}$ and CY Oche ${ }^{3}$ \\ ${ }^{1}$ Department of Chemistry, University of Transkei, Private Bag X1, Unitra,Umtata 5117, South Africa \\ ${ }^{2}$ Department of Botany, University of Transkei, Private Bag X1, Unitra,Umtata 5117, South Africa \\ ${ }^{3}$ Department of Geography, University of Transkei, Private Bag X1, Unitra,Umtata 5117, South Africa
}

\begin{abstract}
The physico-chemical properties of Isinuka springs, a "wonder "water resource in Port St Johns area of Eastern Cape Province, were investigated over three seasonal regimes. Water samples were collected from the five spring sources, along Isinuka river and from Ferry Point Cottage spring and analysed for their quality parameters. Most of the water quality variables measured were found to show seasonal fluctuations. Isinuka spring water is not fresh as it contains high salt contents and the results indicate that it is not suitable for drinking without treatment. The water is moderately hard, salty and fairly neutral with pH ranging from 6.87 to 8.33 . One of the five sources continually emits a characteristic odour and the five spring sources were characterised by very high concentrations of TDS, turbidity, $\mathrm{Cl}^{-}$and $\mathrm{NH}_{4}^{+}-\mathrm{N}$ which exceeded the maximum permissible levels recommended for drinking waters. The $\mathrm{NO}_{3}^{-}-\mathrm{N}$ and $\mathrm{NO}_{2}^{-}-\mathrm{N}$ were, however, present at levels far below the critical value of $10 \mathrm{mg} / \ell$ above which the occurrence of blue baby syndrome (methaemoglobinaemia) due to $\mathrm{NO}_{2}$ - poisoning might be a problem in pregnant women and bottle-fed infants. Water from Ferry Point Cottage spring met the water quality guidelines for drinking water.
\end{abstract}

\section{Introduction}

Surface waters (e.g. rivers, streams and ponds ), groundwater, rainwater and springs are the main sources of water available to the rural settlement dwellers in South Africa. The qualities of these water bodies vary widely depending on location and environmental factors. Among the factors determining the qualities of natural waters, groundwaters and springs in particular, are the chemical composition of the underlying rocks, soil formations and the length of time that the water body has been trapped underground (Van der Merwe, 1962). To protect the water sources, several national and international policies and acts have been enacted (DWAF, 1997; SDWA, 1996;) and criteria and guidelines established for water quality standards (EEC, 1980; SABS, 1984; USEPA, 1996; WHO, 1984 and 1993)

From the data available in the literature, there is an increasing awareness of the need to control the pollution of South African water resources (SWLR, 1995; DWAF,1986) and to protect their quality ( Quilbell et al., 1997; Jagals, et al., 1997 and Dallas and Day, 1993). The present study focuses on the water qualities of Isinuka springs and the adjoining river. The location of the springs has become a popular tourist centre in the Port St Johns' area and is believed to be a mystery water source. The springs are also the main source of domestic water supply for the villagers. Its historical background suggests some latent scientific value which is worthy of investigation. The physico-chemical properties of Isinuka springs are reported and the results are compared with data from the Isinuka River, together with recommended water guidelines for drinking and domestic uses.

Ferry Point Cottage provides the only other spring source available in the Port St Johns' area. In addition to evaluating the suitability of its water for domestic uses, the spring will serve as a

* To whom all correspondence should be addressed.

푱(047) 502-2405; fax (047) 502-2725; e-mail: josh@getafix.utr.ac.za Received 3 November 1999; accepted in revised form 18 December 2000. control and reference. It is also envisaged that the baseline data will contribute to the understanding of the physical and chemical behaviour of other spring sources in the region.

\section{The study areas}

\section{Isinuka springs and river}

Isinuka springs are situated approximately $20 \mathrm{~km}$ west of Port St Johns, a town noted for its beautiful beaches and holiday resorts in the Transkei Region (Fig. 1). There are five spring sources strategically located on top of a mountain about $800 \mathrm{~m}$ a.m.s.l. The springs have long been considered a sacred source in the Eastern Cape Province of South Africa as they are believed to possess some potent qualities and mystical powers for curing all diseases. The location and description of the five spring sources are given in Table 1. Down the mountain valley is the Isinuka River which drains into the Umzimvubu River, an important water body discharging into the Indian Ocean at Port St Johns.

In Isinuka Village, there is a small well associated with the original source of theIsinuka spring. This source dried up when the public was denied free access to the spring and the water was partially commercialised. The well emits a pungent gas and because of this, the area is called "VICKS". Visitors to Isinuka believe that by inhaling the gas their headaches, backaches and other body problems can be cured.

\section{Ferry Point Cottage spring}

Ferry Point Cottage is a bed-and-breakfast $(\mathrm{B} \& \mathrm{~B})$ guest house located by the mountain side south-west of Port St Johns and close to the point where ferries are boarded on Umzimvubu River. The name of the Cottage was derived from its location. The spring's source is on top of the mountain. The management of the cottage depends solely on this water source and are therefore interested in its suitability for drinking and other domestic uses. 


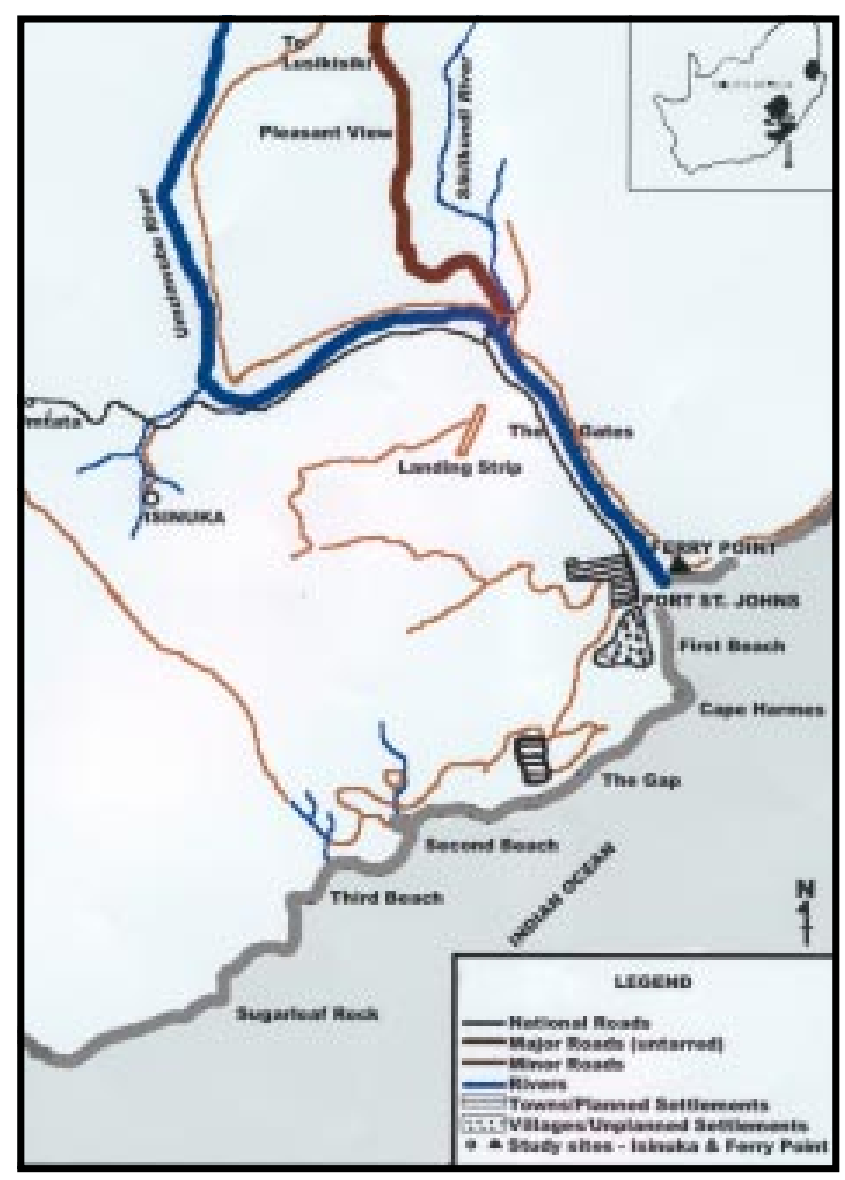

Figure 1

Map of Port St Johns showing Isinuka and Ferry Point locations

\section{Materials and methods}

\section{Sampling protocol}

Water samples were collected from the five Isinuka spring sources once during winter, spring and summer seasons while the river (upstream and downstream) and Ferry Point Cottage spring were sampled over two seasons. Samples for dissolved oxygen (DO) determinations were separately collected in glass bottles while plastic bottles were used for other parameters. The integrity of the DO samples was preserved in the field by the modified Winkler's method (Standard Methods, 1975) and stored in coolers containing ice-chests immediately after collection. The samples were analysed by appropriate certified and acceptable international standard methods (Standard Methods, 1975).

\section{Laboratory analysis}

The physico-chemical variables considered in this study comprised the quality parameters, micro- nutrients and anions. Colour, odour, and taste were observed in the field while the $\mathrm{pH}$, temperature, conductivity and salinity were determined in situ in the field immediately after samples were collected and later in the laboratory. Samples were analysed by both classical and automated instrumental methods as appropriate (Standard Methods, 1975; Skong and Leary, 1992; Hammer, 1975 and Faniran et al., 1994). All the reagents used were of analytical grade and the instruments were pre-calibrated appropriately prior to measurement. Replicate
TABLE 1

Location and description of sampling point

\begin{tabular}{|l|l|}
\hline $\begin{array}{l}\text { Sampling point } \\
\text { and code }\end{array}$ & $\begin{array}{l}\text { Description of sample locations and } \\
\text { field observations }\end{array}$ \\
\hline ISS01 & $\begin{array}{l}\text { Spring Source 1: A pond-like spring about } \\
1 \text { to } 2 \text { m wide is located on top of the moun- } \\
\text { tain. The source emits a characteristic and } \\
\text { unpleasant odour and its water has always } \\
\text { appeared to be cloudy. The sediment which } \\
\text { is darkish-brown, is used by visitors and } \\
\text { other believers in the spring for curing acne } \\
\text { and other skin diseases. }\end{array}$ \\
\hline ISS02 & $\begin{array}{l}\text { Spring Source } 2: \text { The spring is approximately } \\
\text { 1.5 m from Source 1 on top of the mountain. } \\
\text { It has a very narrow spout about } 10 \text { to } 15 \mathrm{~cm} \\
\text { in diameter. The water is tasty, odourless, } \\
\text { colourless and clear. }\end{array}$ \\
\hline ISS07
\end{tabular}




\begin{tabular}{|c|c|c|c|c|c|}
\hline \multicolumn{6}{|c|}{$\begin{array}{c}\text { TABLE } 2 \\
\text { Water quality of Isinuka springs during the winter season }\end{array}$} \\
\hline Parameter & ISS01 & ISS02 & ISS03 & ISS04 & ISS05 \\
\hline 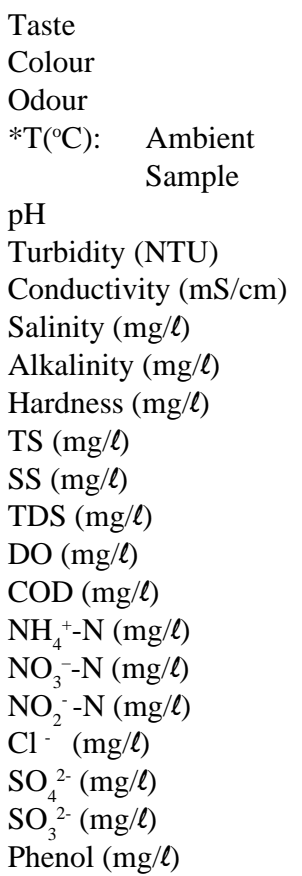 & $\begin{array}{c}\text { Not tastable } \\
\text { Cloudy } \\
\text { Emits odour } \\
20 \\
16 \\
8.65 \\
63.20 \\
3.40 \\
2.90 \\
370.7 \\
121.8 \\
2098 \\
91.80 \\
2006 \\
10.87 \\
1151 \\
0.51 \\
0.39 \\
0.57 \\
699.7 \\
144.67 \\
1.40 \\
1.11\end{array}$ & $\begin{array}{c}\text { Tasty } \\
\text { Colourless } \\
\text { Odourless } \\
20 \\
18 \\
8.52 \\
0.31 \\
9.01 \\
5.10 \\
515.3 \\
114.4 \\
3833 \\
47.80 \\
3585 \\
15.47 \\
7841 \\
30.13 \\
0.01 \\
0.09 \\
1050 \\
92.67 \\
0.30 \\
0.03\end{array}$ & $\begin{array}{c}\text { Tasty } \\
\text { Colourless } \\
\text { Odourless } \\
20 \\
18 \\
7.42 \\
0.32 \\
9.16 \\
5.20 \\
590.0 \\
121.4 \\
4600 \\
42.30 \\
4558 \\
13.73 \\
5441 \\
17.23 \\
0.01 \\
0.01 \\
1086 \\
78.33 \\
0.30 \\
0.02\end{array}$ & $\begin{array}{c}\text { Tasty } \\
\text { Colourless } \\
\text { Odourless } \\
17 \\
18 \\
9.36 \\
1.73 \\
8.86 \\
5.00 \\
554.7 \\
109.8 \\
4292 \\
40.70 \\
4252 \\
14.33 \\
1592 \\
20.83 \\
0.16 \\
0.01 \\
1018 \\
95.33 \\
0.20 \\
0.12\end{array}$ & $\begin{array}{c}\text { Not tastable } \\
\text { Cloudy } \\
\text { Odourless } \\
17 \\
18 \\
7.98 \\
\text { nd } \\
8.21 \\
4.60 \\
438.3 \\
91.76 \\
3332 \\
40.90 \\
3291 \\
13.70 \\
4828 \\
11.17 \\
0.18 \\
0.03 \\
953.0 \\
83.67 \\
0.53 \\
0.26\end{array}$ \\
\hline
\end{tabular}

analyses were carried out for each determination to ascertain reproducibility and quality assurance.

The $\mathrm{pH}$ was measured in the field with a Merck Model WTW $320 \mathrm{pH}$ meter and in the laboratory using a Hanna Microprocessor Bench Model HI931400 pH meter. Both instruments were calibrated with standard buffers at $\mathrm{pH} 4, \mathrm{pH} 7$ and $\mathrm{pH} 10$.

The turbidity was determined using a Cole Palmer turbidimeter model $8391-45$ while the conductivity, salinity and total dissolved solids (TDS) determinations were carried out on Merck conductivity meter Model WTW LF597, a multiCal-calibration system with integrated test value memory. The TDS was further analysed gravimetrically using glass-fibre filter papers.

The anions, micro-nutrients, chemical oxygen demand (COD) and phenol were analysed by photometric method on Merck Spectroquant Model SQ118 Photometer. Samples for COD analysis were digested with Merck Thermoreactor Model TR300. Dissolved oxygen (DO) was measured with a YSI Dissolved Oxygen Meter Model 5000 and by Winkler's method. Total dissolved solids (TDS) and suspended solids (SS) were analysed gravimetrically as previously described (Faniran et al., 1994).

Total alkalinity (as $\mathrm{mg} / \ell \mathrm{CaCO}_{3}$ ), total hardness and the chloride concentrations in the water samples were measured by titrimetric methods. The alkalinity was measured by titration of the sample with $0.1 \mathrm{M}$ hydrochloric acid to $\mathrm{pH} 4.5$ using methyl orange indicator while the water hardness was analysed by titration of the buffered water sample with standard EDTA at pH 10 using Eriochrome Black-T as the indicator. The chloride content was determined by argentometric method. The sample was titrated under neutral conditions with a standard silver nitrate solution using potassium chromate as the indicator.

\section{Results and discussion}

\section{Isinuka River and spring}

The physical and chemical characteristics of Isinuka spring and river water for the different seasons are presented in Tables 2 to 5 . The mean concentrations of the five spring sources are given in Table 6 and compared in Table 7 with the acceptable limits recommended by the South Africa Bureau of Standards (SABS, 1984), United States Environmental Protection Agency (USEPA, 1996) and World Health Organisation (WHO,1984 and 1993). Similar comparisons for water quality parameters of Isinuka River and Ferry Point Cottage spring are shown in Tables 8 and 9. The variation of the mean values of Isinuka spring water quality parameters are given in Figs. 2 to 6.

\section{General characteristics}

Water samples collected from the five spring sources had a good taste and were odourless except spring Source 1 which continuously emitted an unpleasant characteristic smell through-out the period of investigation. Sources 1 and 5 were always cloudy and continually impacted by human activities while the other three sources were clear and colourless. On the other hand, Isinuka River water was tasteless, odourless and colourless. From Tables 2 to 5, it will be observed that the sample temperatures were generally lower than 


\begin{tabular}{|c|c|c|c|c|c|}
\hline \multicolumn{6}{|c|}{$\begin{array}{c}\text { TABLE } 3 \\
\text { Water quality of Isinuka springs during the spring season }\end{array}$} \\
\hline Parameter & ISS01 & ISS02 & ISS03 & ISS04 & ISS05 \\
\hline Taste & Not tastable & Tasty & Tasty & Tasty & Not tastable \\
\hline Colour & Cloudy & Colourless & Colourless & Colourless & Cloudy \\
\hline Odour & Emits odour & Odourless & Odourless & Odourless & Odourless \\
\hline${ }^{*} \mathrm{~T}\left({ }^{\mathrm{O}} \mathrm{C}\right)$ : Ambient & 22 & 22 & 21 & 21 & 20 \\
\hline Sample & 14 & 16 & 16 & 17 & 15 \\
\hline $\mathrm{pH}$ & 7.84 & 7.72 & 8.33 & 7.70 & 6.73 \\
\hline Turbidity (NTU) & 85.53 & 66.57 & 5.65 & 1.76 & nd \\
\hline Conductivity $(\mathrm{mS} / \mathrm{cm})$ & 5.45 & 8.63 & 9.45 & 9.01 & 8.49 \\
\hline Salinity $(\mathrm{mg} / \ell)$ & 2.93 & 4.90 & 3.40 & 5.10 & 4.77 \\
\hline Alkalinity $(\mathrm{mg} / \ell)$ & 63.90 & 78.30 & 165.0 & 3.30 & 118.3 \\
\hline Hardness (mg/l) & 229.0 & 116.8 & 137.5 & 186.6 & 98.53 \\
\hline $\mathrm{TS}(\mathrm{mg} / \ell)$ & 1622 & 2936 & 3351 & 2895 & 2761 \\
\hline $\mathrm{SS}(\mathrm{mg} / \ell)$ & 63.40 & 41.70 & 37.90 & 38.50 & 42.60 \\
\hline TDS (mg/l) & 1559 & 2894 & 3317 & 2857 & 2718 \\
\hline $\mathrm{DO}(\mathrm{mg} / \ell)$ & 13.47 & 12.50 & 12.50 & 12.13 & 12.33 \\
\hline $\mathrm{COD}(\mathrm{mg} / \mathrm{l})$ & 945.3 & 1216 & 4712 & 2626 & 2844 \\
\hline $\mathrm{NH}_{4}^{+}-\mathrm{N}(\mathrm{mg} / \ell)$ & 7.75 & 7.76 & 5.55 & 4.81 & 3.03 \\
\hline $\mathrm{NO}_{3}{ }^{-}-\mathrm{N}(\mathrm{mg} / \mathrm{l})$ & $\mathrm{Nd}$ & $\mathrm{Nd}$ & $\mathrm{Nd}$ & $\mathrm{Nd}$ & $\mathrm{Nd}$ \\
\hline $\mathrm{NO}_{2}{ }^{3}-\mathrm{N}(\mathrm{mg} / \mathrm{l})$ & 0.48 & 0.07 & 0.02 & 0.02 & 0.03 \\
\hline $\mathrm{Cl}^{-2}(\mathrm{mg} / \mathrm{l})$ & 625.7 & 1016 & 1144 & 1091 & 1027 \\
\hline $\mathrm{SO}_{4}{ }^{2-}(\mathrm{mg} / \ell)$ & 144.3 & 155.0 & 99.33 & 131.0 & 98.33 \\
\hline $\mathrm{SO}_{3}^{2-}(\mathrm{mg} / \ell)$ & 14.50 & 1.90 & 0.90 & 1.01 & 7.53 \\
\hline Phenol (mg/l) & 0.62 & 1.13 & 0.35 & 0.41 & 0.08 \\
\hline \multicolumn{6}{|c|}{ nd: Above max. detection limit; $\quad$ Nd: Not determined; } \\
\hline
\end{tabular}

\begin{tabular}{|c|c|c|c|c|c|}
\hline \multicolumn{6}{|c|}{$\begin{array}{c}\text { TABLE } 4 \\
\text { Water quality of Isinuka springs during the summer season }\end{array}$} \\
\hline Parameter & ISS01 & ISS02 & ISS03 & ISS04 & ISS05 \\
\hline Taste & Not tastable & Tasty & Tasty & Tasty & Not tastable \\
\hline Colour & Cloudy & Colourless & Colourless & Colourless & Cloudy \\
\hline Odour & Emits odour & Odourless & Odourless & Odourless & Odourless \\
\hline$* \mathrm{~T}\left({ }^{\circ} \mathrm{C}\right):$ Ambient & 25 & 25 & 23 & 23 & 24 \\
\hline Sample & 24 & 22 & 21 & 21 & 24 \\
\hline $\mathrm{pH}$ & 7.26 & 6.87 & 6.98 & 7.31 & 7.91 \\
\hline Turbidity (NTU) & 86.83 & 2,27 & 1.62 & 1.42 & nd \\
\hline Conductivity (mS/cm) & 8.45 & 9.22 & 9.27 & 8.97 & 8.95 \\
\hline Salinity $(\mathrm{mg} / \ell)$ & 5.10 & 5.20 & 5.20 & 5.10 & 4.80 \\
\hline Alkalinity (mg/l) & 506.7 & 688.7 & 234.7 & 258.8 & 236.7 \\
\hline Hardness (mg/l) & 328.2 & 226.2 & 293.0 & 280.7 & 170.7 \\
\hline $\mathrm{TS}(\mathrm{mg} / \ell)$ & 3534 & 3398 & 3479 & 3403 & 3161 \\
\hline $\mathrm{SS}(\mathrm{mg} / \ell)$ & 69.60 & 39.10 & 31.70 & 47.10 & 46.20 \\
\hline TDS (mg/८) & 3465 & 3359 & 3447 & 3356 & 3115 \\
\hline $\mathrm{DO}(\mathrm{mg} / \ell)$ & 1.73 & 6.23 & 7.87 & 9.83 & 9.87 \\
\hline $\mathrm{COD}(\mathrm{mg} / \ell)$ & 67.00 & 471.3 & 342.7 & 1982 & 2193 \\
\hline $\mathrm{NH}_{4}^{+}-\mathrm{N}(\mathrm{mg} / \ell)$ & 5.41 & 1.29 & 1.59 & 1.75 & 2.26 \\
\hline $\mathrm{NO}_{3}^{-}-\mathrm{N}(\mathrm{mg} / \ell)$ & 0.90 & 7.20 & 0.13 & 3.23 & 3.57 \\
\hline $\mathrm{NO}_{2}^{-}-\mathrm{N}(\mathrm{mg} / \ell)$ & 0.12 & 0.01 & 0.01 & 0.01 & 0.08 \\
\hline $\mathrm{Cl}^{-2}(\mathrm{mg} / \mathrm{l})$ & 1223 & 1205 & 1148 & 1150 & 1113 \\
\hline $\mathrm{SO}_{4}^{2-}(\mathrm{mg} / \ell)$ & 125.7 & 123.3 & 73.00 & 57.00 & 70.33 \\
\hline $\mathrm{SO}_{3}^{2-}(\mathrm{mg} / \ell)$ & 3.10 & 0.60 & 0.50 & 0.50 & 1.50 \\
\hline Phenol (mg/l) & 2.66 & 0.07 & 0.12 & 0.09 & 1.10 \\
\hline
\end{tabular}




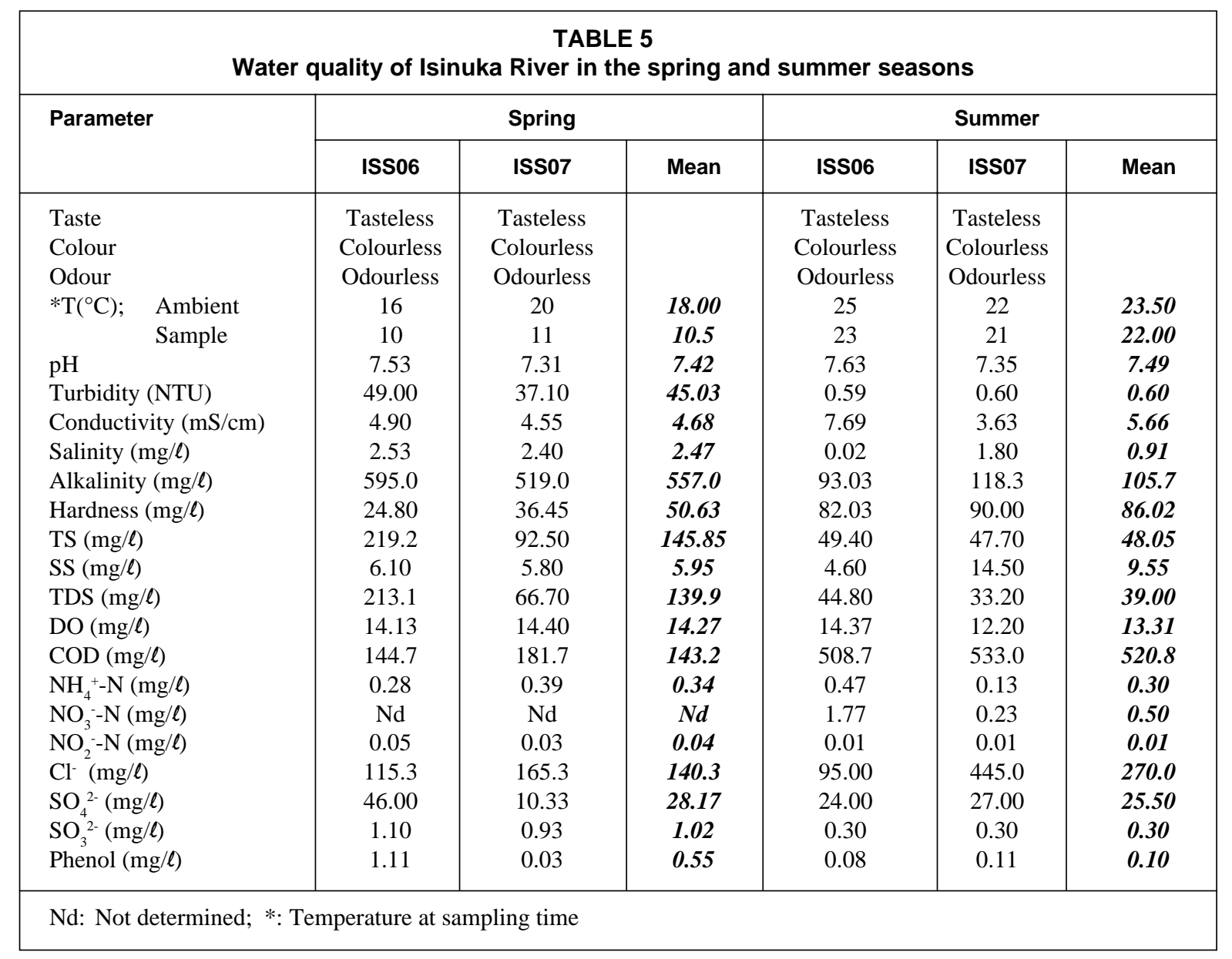

\section{TABLE 6}

The mean values and range of the water quality of the five Isinuka springs in winter, spring and summer seasons

\begin{tabular}{|c|c|c|c|c|c|c|}
\hline \multirow[t]{2}{*}{ Parameter } & \multicolumn{2}{|c|}{ Winter } & \multicolumn{2}{|c|}{ Spring } & \multicolumn{2}{|c|}{ Summer } \\
\hline & Mean & Range & Mean & Range & Mean & Range \\
\hline$* \mathrm{~T}\left({ }^{\circ} \mathrm{C}\right):$ Ambient & 18.80 & $17-20$ & 21.20 & $20-22$ & 24.00 & $23-25$ \\
\hline Sample & 17.60 & $16-18$ & 15.60 & $14-17$ & 22.40 & 21-24 \\
\hline $\mathrm{pH}$ & 8.15 & $7.42-8.65$ & 7.70 & $6.73-8.53$ & 7.21 & $6.87-7.91$ \\
\hline Turbidity (NTU) & 16.39 & $0.31-63.20$ & 39.83 & $1.76-85.53$ & 25.54 & $1.42-86.83$ \\
\hline Conductivity $(\mathrm{mS} / \mathrm{cm})$ & 8.13 & $3.40-9.16$ & 8.21 & $5.45-9.45$ & 8.97 & $8.45-9.27$ \\
\hline Salinity $(\mathrm{mg} / \ell)$ & 4.56 & $2.90-5.20$ & 4.62 & $2.93-5.10$ & 5.15 & $4.80-5.20$ \\
\hline Alkalinity $(\mathrm{mg} / \ell)$ & 493.8 & $370.7-590.0$ & 85.76 & $3.30-165.0$ & 385.1 & $234.7-688.7$ \\
\hline Hardness (mg/l) & 111.6 & $91.76-121.83$ & 153.7 & $98.53-229.0$ & 259.7 & $170.7-328.2$ \\
\hline $\mathrm{TS}(\mathrm{mg} / \mathrm{l})$ & 3512 & $2098-4600$ & 2813 & $1622.3-3351$ & 3395 & $3161-3534$ \\
\hline $\mathrm{SS}(\mathrm{mg} / \ell)$ & 55.66 & $40.70-91.80$ & 44.82 & $37.90-63.40$ & 46.74 & $31.70-69.60$ \\
\hline TDS (mg/l) & 3539 & $2006-4558$ & 2690 & $1559-3317$ & 3348 & $\begin{array}{llll}3 & 115 & -3 & 464.7\end{array}$ \\
\hline $\mathrm{DO}(\mathrm{mg} / \ell)$ & 13.62 & $10.87-15.47$ & 12.59 & $12.13-13.47$ & 7.11 & $1.73-9.87$ \\
\hline $\mathrm{COD}(\mathrm{mg} / \ell)$ & 4171 & $1151-7841$ & 2469 & $945.3-4712$ & 1011 & $67.00-2193$ \\
\hline $\mathrm{NH} 4+-\mathrm{N}(\mathrm{mg} / \ell)$ & 15.99 & $0.51-30.13$ & 5.78 & $3.03-7.76$ & 2.46 & $1.29-5.41$ \\
\hline $\mathrm{NO} 3--\mathrm{N}(\mathrm{mg} / \ell)$ & 0.15 & $0.01-0.39$ & $N d$ & $\mathrm{Nd}$ & 3.01 & $0.13-7.20$ \\
\hline NO2 --N (mg/l) & 0.14 & $0.01-0.57$ & 0.17 & $0.01-0.48$ & 0.06 & $0.01-0.12$ \\
\hline $\mathrm{Cl}-(\mathrm{mg} / \ell)$ & 960.9 & 699.7- 1086 & 980.6 & $625.7-1144$ & 1188 & $1113-1223$ \\
\hline SO4 2- $(\mathrm{mg} / \ell)$ & 98.93 & $78.33-144.7$ & 125.6 & $98.33-155.0$ & 89.87 & $57.00-125.7$ \\
\hline SO3 2- $(\mathrm{mg} / \mathrm{l})$ & 0.55 & $0.02-1.40$ & 5.17 & $0.90-14.50$ & 1.24 & $0.50-3.10$ \\
\hline Phenol (mg/l) & 0.32 & $0.02-1.11$ & 0.52 & $0.08-1.13$ & 0.81 & $0.08-1.13$ \\
\hline
\end{tabular}




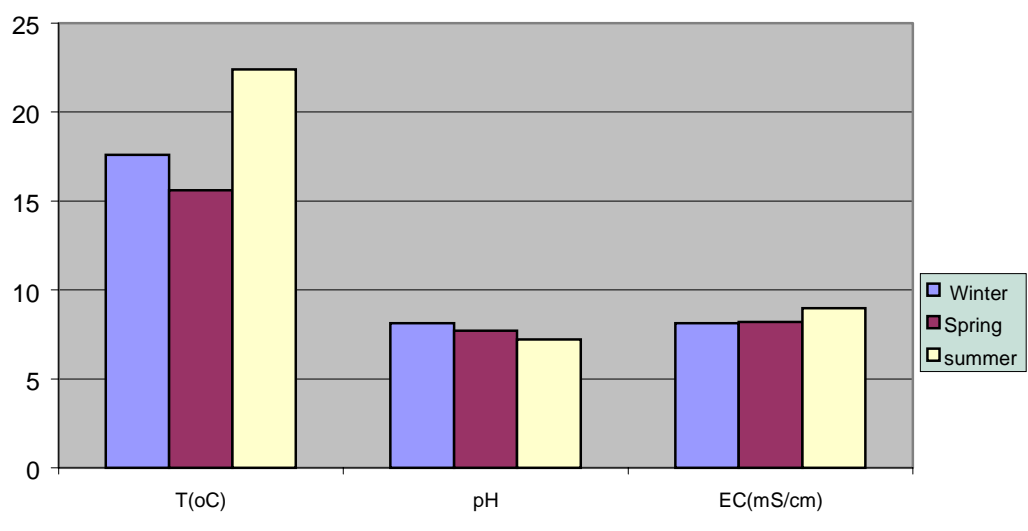

Figure 2

Seasonal variations of the mean values of temperature, $\mathrm{pH}$ and conductivity $(\mathrm{m} / \mathrm{S} / \mathrm{cm})$ in Isinuka springs

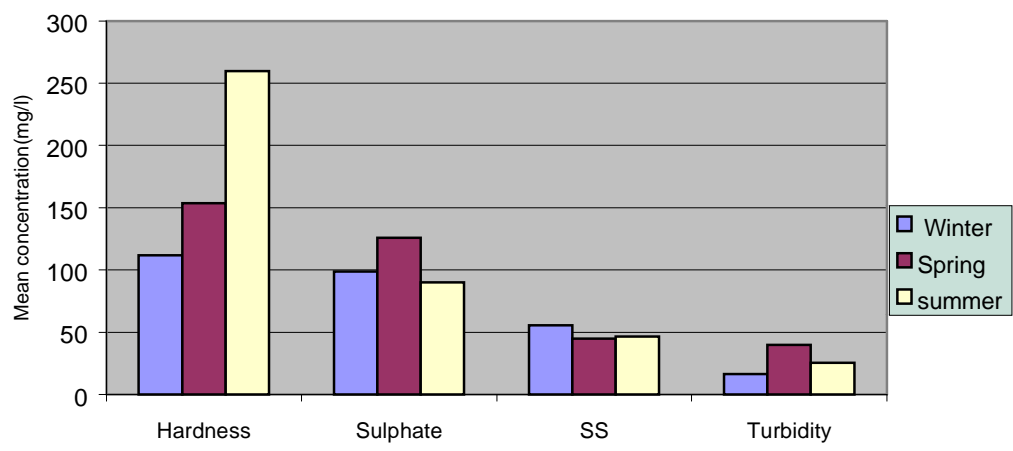

Figure 3

Seasonal variation of the mean concentrations ( $\mathrm{mg} / \mathrm{l})$ of $\mathrm{SO}_{4}^{2-}, \mathrm{DO}$, hardness, $\mathrm{SS}$ and turbidity in Isinuka springs

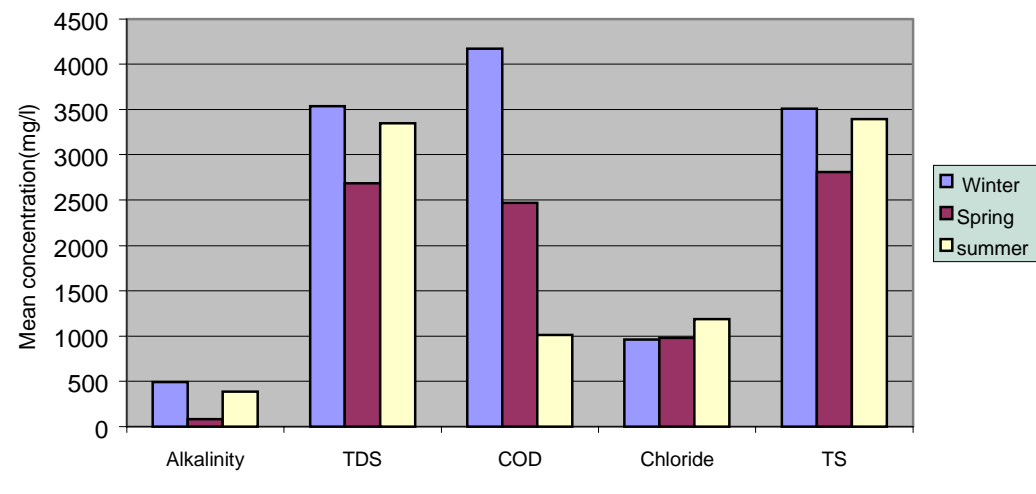

Figure 4

Seasonal variation of the mean concentrations $(\mathrm{mg} / \mathrm{l})$ of $\mathrm{Cl}$, alkalinity, TDS, TS and $C O D$ in Isinuka springs

the ambient temperatures. Shown in Fig. 2 is the variation of the mean values of sample temperatures over the sampling seasons.

\section{pH}

The $\mathrm{pH}$ of the springs varied from 6.73 to 8.33 and, over the three seasons of investigation, fell within the range of $\mathrm{pH} 4$ to $\mathrm{pH} 9$ associated with most natural water and 6.5 to 8.5 stipulated for drinking and domestic waters. The springs are slightly basic in winter and spring with $\mathrm{pH}$ means of 8.15 and 7.7 respectively and neutral in summer (mean $\mathrm{pH}=7.21$ ) except Source 5 (the clay-like source) which is slightly neutral $(\mathrm{pH}=6.73)$ in spring and slightly basic in summer $(\mathrm{pH}=7.91)$. Figure 2 depicts a decreasing response of $\mathrm{pH}$ of the springs to seasonal changes from winter to summer. The river is, however, neutral ( $\mathrm{pH}$ range $=7.3$ to 7.63 ) and relatively unaffected by seasonal variation (Table 5).

\section{Conductivity}

The conductivity of the springs and river water is within the limits of acceptable standards for domestic water and did not vary significantly over the sampling seasons except spring Source1. As shown in Table 6 and Fig. 2, the mean conductivity of the springs increased from winter $($ mean $=8.13 \mathrm{mS} / \mathrm{cm})$ through spring $($ mean $=8.21 \mathrm{mS} / \mathrm{cm})$ to summer $($ mean $=8.97$ $\mathrm{mS} / \mathrm{cm}$ ). The same trend was observed for the river with a mean of $4.60 \mathrm{mS} / \mathrm{cm}$ in spring and $5.66 \mathrm{mS} / \mathrm{cm}$ in summer (Table 5). However, the conductivity of the Isinuka River water was generally slightly lower than those of the springs.

\section{Turbidity, SS and TDS}

Tables 6 and 7 show that the mean values of turbidity, SS and TDS of the springs are high and fall outside the maximum recommended limits for domestic and drinking waters. As can be seen in Fig. 3, the turbidity was highest in the spring (mean=39.83 NTU) and lowest in winter $($ mean $=16.39 \mathrm{NTU})$. The river was fairly turbid in spring with a mean of 43.05 NTU compared to the recommended value of 5 NTU but very low in summer ( $0.60 \mathrm{NTU})$.

SS and TDS are common indicators of polluted waters. As shown in Table 7, the maximum recommended concentration for TDS in drinking waters by SABS (1984) is $450 \mathrm{mg} / \ell$ compared to 500 $\mathrm{mg} / \ell$ by USEPA (1996) and $1000 \mathrm{mg} / \ell$ by WHO (1993). The mean values of TDS for the springs in winter, spring and summer seasons were $3538.38,2$ 688.98 and $3348.20 \mathrm{mg} / \ell$ respectively (Table 6 ).

These not only exceeded the maximum acceptable limits but are also greater than $2450 \mathrm{mg} / \ell$ considered to be the critical value above which some longerterm health problems might be anticipated due to excessive concentrations of dissolved particles in water (Kempster et al., 1997). Spring Source 1 had the highest SS contents. It was generally above $60 \mathrm{mg} / \mathrm{l}$ throughout the study period as compared to the other springs where the concentrations were below $50 \mathrm{mg} / \ell$ (Tables 2 to 4 ). The variations of the mean values of SS and TDS with seasonal changes are given in Figs. 3 and 4. For the Isinuka River, the corresponding mean values of TDS were 139.90 and $39.00 \mathrm{mg} / \ell$ in spring and summer while the SS means were 5.95 and $9.55 \mathrm{mg} / \ell$ respectively.

\section{Salinity and chloride levels}

Although no standard has been established for salinity of domestic waters, Tables 2 to 4 show that the springs are saline and are by no means freshwater bodies. The salinity varied from $2.90 \mathrm{mg} / \ell$ in spring Source 1 in winter to $5.20 \mathrm{mg} / \mathrm{l}$ in spring Source 3 during winter and summer. With the exception of Source 1, the salinity of the springs is virtually unaffected by seasonal changes. The increase 
TABLE 9

Water quality of Ferry Point Cottage spring compared with the limits recommended for drinking waters

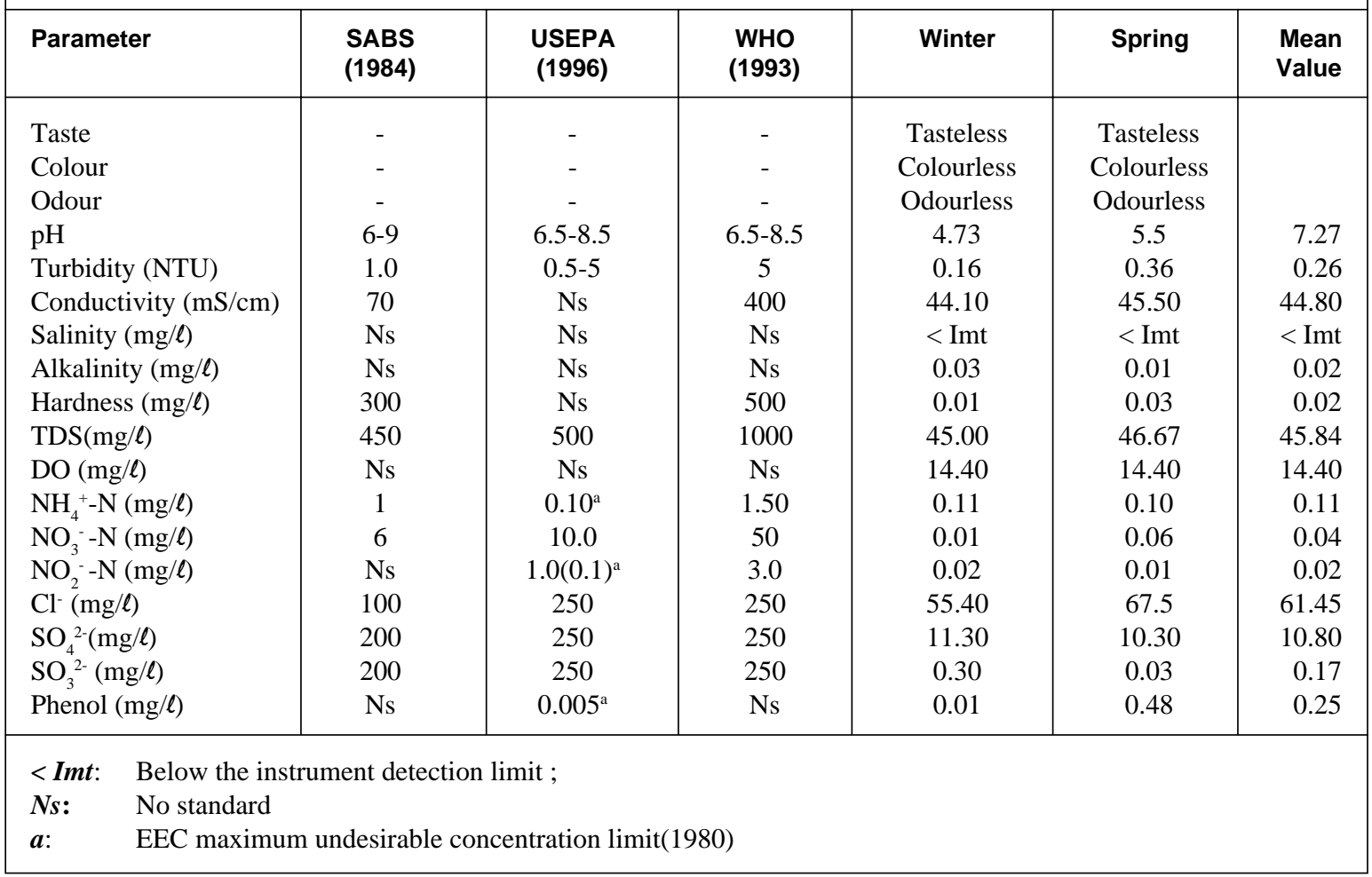

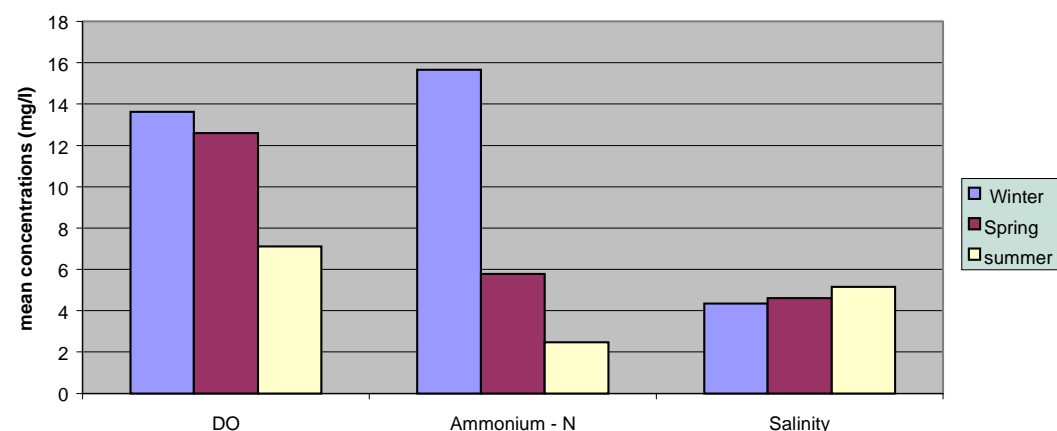

Figure 5

Seasonal variation of the mean concentrations (mg/l) of salinity, $\mathrm{DO}$ and $\mathrm{NH}_{4}^{+}{ }^{+} \mathrm{N}$ in Isinuka springs

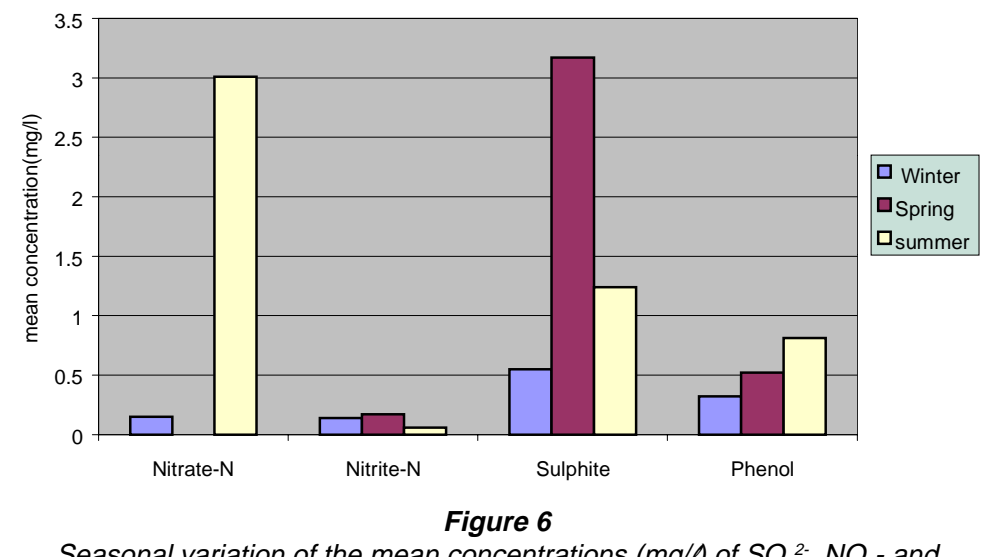

Seasonal variation of the mean concentrations $(\mathrm{mg} / \mathrm{l})$ of $\mathrm{SO}_{3}{ }^{2-}, \mathrm{NO}_{2}{ }_{-}$and phenol in Isinuka springs river water by human activities in the pond close to the sampling point downstream during the summer months. As indicated in Table 5, the $\mathrm{Cl}^{-}$ concentration upstream was $95.0 \mathrm{mg} / \ell$ compared to $445.0 \mathrm{mg} / \ell$ downstream.

\section{Dissolved oxygen (DO), chemical oxygen} demand (COD) and phenol

Water from the five spring sources had very high COD concentrations and low DO levels. The mean values were $4170 \mathrm{mg} / \ell$ in winter, $2469 \mathrm{mg} / \ell$ in spring and $1011 \mathrm{mg} / \ell$ in summer. The mean values for DO during the same periods were 13.62, 10.59 and $7.11 \mathrm{mg} / \ell$ respectively. Thus, both COD and DO are sensitive to seasonal changes (Figs. 4 and 5) as might be expected. Although the amount of phenol in the springs as shown in Tables 2 to 4 appears to be very low ( 0.02 to $2.66 \mathrm{mg} / \ell)$, the levels are above the maximum limit of $0.005 \mathrm{mg} / \ell$ recommended by the Ministry of Health and Welfare, Japan, for domestic waters. As observed earlier, spring Source 1 which is the most popular of all five sources, had the largest accumulation of phenol in each of the three seasons. While both COD and DO decreased from winter to summer (Figs. 4 and 5), the phenol concentrations increased by a factor of two from season to season between winter and summer (Fig.6).

In contrast, the Isinuka River water has low concentrations of COD and higher levels of DO compared to the spring sources during the same 
period. This seems to confirm that the river is a freshwater body and will support aquatic life. The mean values of the phenol contents were 0.55 and $0.10 \mathrm{mg} / \ell$ in spring and summer respectively.

\section{The micronutrients}

The amounts of nitrate, nitrite and ammonia present in natural waters in the form of nitrogen are of great interest because of their nutrient values. $\mathrm{NH}_{4}^{+}-\mathrm{N}, \mathrm{NO}_{3}^{-}-\mathrm{N}$ and $\mathrm{NO}_{2}^{-}-\mathrm{N}$ are considered to be non-cumulative toxins (Dallas and Day, 1993). When present in high concentrations, $\mathrm{NO}_{3}^{-}-\mathrm{N}$ and $\mathrm{NO}_{2}^{-}-\mathrm{N}$ may give rise to potential health risks particularly in pregnant women and bottle-fed infants (Kempster et al., 1997; Kelter et al., 1997; Cotruvo, 1988; Bush and Mayer, 1982). $\mathrm{NO}_{2}^{-}-\mathrm{N}$ poisoning causes the blue baby syndrome (methaemoglobinaemia). It has also been alleged that livestock can also be affected by nitrite poisoning (Kelter et al., 1997). At elevated concentrations $\mathrm{NO}_{3}^{-}-\mathrm{N}$ is also known to result in cyanosis in infants (Comly, 1945). Ammonia is naturally present in surface water and groundwater and can be produced by the de-amination of organic nitrogen containing compounds and by the hydrolysis of urea. The problem of taste and odour may, however, arise when the $\mathrm{NH}_{4}^{+}-\mathrm{N}$ level is greater than $2 \mathrm{mg} / \ell$. Above $10 \mathrm{mg} / \ell$, appreciable amounts of $\mathrm{NO}_{3}^{-}-\mathrm{N}$ may be produced from $\mathrm{NH}_{4}{ }^{+} \mathrm{N}$ under suitable anaerobic conditions ( WHO, 1993; Kempster et al., 1997).

The mean concentrations of these micro-nutrients are listed in Tables 5 and 6 for the Isinuka River and springs respectively. These parameters are seen to be sensitive to seasonal changes (Figs. 5 and 6). Due to loss of some samples, the nitrate concentrations were not determined in the spring season.. Water from the springs and river had very low concentrations of $\mathrm{NO}_{3}^{-}-\mathrm{N}$ and $\mathrm{NO}_{2}^{-}-\mathrm{N}$ which are within the recommended limits. However, the $\mathrm{NH}_{4}^{+}-\mathrm{N}$ level in the springs is above the permissible limits of 0.50 to $1.50 \mathrm{mg} / \ell$ (Table 7). As shown in Fig. 5, it is highest in winter (mean $=15.99$ $\mathrm{mg} / \ell$ and lowest in summer $($ mean $=2.82 \mathrm{mg} / \ell$ ). In the river, the mean concentrations of $\mathrm{NH}_{4}{ }^{+}-\mathrm{N}$ are fairly constant over the sampling period $(0.34$ and $0.30 \mathrm{mg} / \ell)$ and are within the recommended guidelines (Tables 5 and 8 ).

\section{Sulphate and sulphite contents}

Water from Isinuka springs is believed to be a cure for constipation and other stomach problems when the water is taken in excess. Although it is within the maximum acceptable SABS recommended limits of 0 to $200 \mathrm{mg} / \ell$ and classified as a non-toxin, intake of $\mathrm{SO}_{4}{ }^{2-}$ ions at elevated concentrations can cause diarrhoea (Kempster et al., 1997). The springs have appreciable levels of $\mathrm{SO}_{4}^{2}$-ion contents which range from $55 \mathrm{mg} / \ell$ to $155 \mathrm{mg} / \ell$ depending on the time of collection and the season (Table 6, Fig. 3). The mean concentrations in winter, spring and summer periods for example, were 98.93 , 125.6 and $89.87 \mathrm{mg} / \ell$ respectively.

The $\mathrm{SO}_{3}{ }^{2-}$ ion concentrations in the springs ranged from 0.20 $\mathrm{mg} / \mathrm{l}$ in winter from Source 4 to $14.50 \mathrm{mg} / \mathrm{l}$ in spring from source one. The available amount of $\mathrm{SO}_{3}{ }^{2-}$ is lowest in winter (mean $=0.55$ $\mathrm{mg} / \ell)$ and highest in spring $(\mathrm{mean}=5.17 \mathrm{mg} / \ell)$. These concentrations although relatively small, are very significant for drinking waters (EPA, 1994; Cotruvo, 1988; HWC, 1987 ). The mean values of $\mathrm{SO}_{3}{ }^{2-}$ concentrations in the river were $1.02 \mathrm{mg} / \ell$ and $0.30 \mathrm{mg} / \ell$ in spring and summer respectively. The seasonal variations of the $\mathrm{SO}_{4}^{2-}$ and $\mathrm{SO}_{3}^{2-}$ concentrations are shown in Figs. 3 and 6.

\section{Hardness and alkalinity}

In both winter and summer seasons, the five springs exhibited a rather unusually high alkaline nature with means of 493.3 and $385.1 \mathrm{mg} / \ell$ as $\mathrm{CaCO}_{3}$ respectively. These dropped to $85.71 \mathrm{mg} / \ell$ over a range of 3.30 to $165.00 \mathrm{mg} / \ell$ in spring (Fig 4). On the other hand, the mean value for the river was $557.0 \mathrm{mg} / \mathrm{l}$ in spring and $105.7 \mathrm{mg} / \ell$ in the summer.

The results shown in Tables 5 and 6 indicate that Isinuka River water is soft in spring (mean hardness $30.60 \mathrm{mg} / \ell$ ) and becomes moderately hard in summer with a mean of $86.02 \mathrm{mg} / \ell$. (Fig. 3). Water from the spring sources is moderately hard in winter (mean $=111.64 \mathrm{mg} / \ell)$, hard in spring $($ mean $=153.69 \mathrm{mg} / \ell)$ and very hard in summer with a mean level of $259.76 \mathrm{mg} / \ell$ (Fig. 3).

\section{The socio-economic impact of Isinuka springs}

Water is vital to life. It promotes the economic and the general wellbeing of the society through its diverse and beneficial uses. From the preliminary analysis of the structured socio-economic questionnaires and oral interviews, all the visitors to Isinuka springs have a strong belief that the spring water and the sediments are the answers to their ailments. They consider it to be an economically cheaper source, a faster and more effective way of treating all human diseases when compared to what it would cost to visit a regular health clinic (traditional or orthodox). The majority of them also believed that the efficacy of the spring water will be affected if protected or commercialised.

There is, therefore, a need to educate the general public about the enormous benefits to be derived from adequate management and conservation of the springs and their environment. The deleterious health effects that may result from prolonged intake of the spring water should also be emphasised without jeopardising the faith of the people. This will be consistent with the South Africa National Policy on water resource management ( SWLR, 1995; DWAF, 1993; DWAF, 1997).

\section{The Ferry Point Cottage spring}

The Ferry Point Cottage spring water quality parameters are compared with the values recommended by SABS and other international bodies for drinking and domestic waters (see Table 9). The water is colourless and odourless. Except for the $\mathrm{pH}$ which is between 4.73 and 5.53, the measured spring's water quality values fall within the recommended drinking and domestic water guidelines for chemical variables.

The mean concentrations of turbidity, TDS and $\mathrm{Cl}^{-}$ions were $0.26 \mathrm{NTU}, 45.84 \mathrm{mg} / \ell$ and $61.45 \mathrm{mg} / \ell$ respectively over the two sampling seasons. These are below the maximum limits of $5 \mathrm{NTU}$, $500 \mathrm{mg} / \ell$ and $100 \mathrm{mg} / /$ recommended for drinking waters by SABS (1984). The mean value of the conductivity was $44.80 \mathrm{mS} / \mathrm{cm}$ which is a factor of five higher than the mean conductivity of Isinuka springs of $8.17 \mathrm{mS} / \mathrm{cm}$ during the same period. The mean $\mathrm{pH}$ of the spring was 5.13. This indicates that the water is acidic while the mean DO concentration of $14.4 \mathrm{mg} / \ell$ is comparable to that of the Isinuka River.

Both the alkalinity and hardness of Ferry Cottage spring water had a mean concentration of $0.02 \mathrm{mg} / \ell$ over the sampling period. The salinity was, however, below the detection limit of the instrument. The predominant anions during the same period were $\mathrm{Cl}^{-}$ $($ mean $=61.45 \mathrm{mg} / \ell)$ and $\mathrm{SO}_{4}{ }^{2-}($ mean $=10.80 \mathrm{mg} / \ell)$ while phenol was found to be concentrated at $0.25 \mathrm{mg} / \ell$ mean levels. These concentrations are below the minimum toxic levels of the anions. Even though Ferry Point Cottage spring source adjoins the Indian Ocean, the generally low values obtained for conductivity, $\mathrm{Cl}^{-}$, $\mathrm{SO}_{4}{ }^{2-}$ and salinity show that the cottage spring is a freshwater body and is unpolluted by salt-water intrusion from the sea. 


\section{Conclusions}

The "wonder water" of Isinuka springs is not a freshwater body, generally hard and unsuitable for drinking in its present form without adequate treatment. The study indicates that most of the physical and chemical constituents of the five spring sources and in particular TDS, turbidity, $\mathrm{NH}_{4}^{+}-\mathrm{N}_{\text {and }} \mathrm{Cl}^{-}$, are above the maximum limits recommended for drinking water. These parameters are considered to be "hot spots" in Isinuka springs which should be monitored over a period of time because of possible threats to health at elevated concentrations.

The concentrations of $\mathrm{SO}_{4}^{2-}$ and phenol are at such elevated levels where serious health effects and risks might arise after prolonged and continuous intake. The results however, showed that $\mathrm{NO}_{2}^{-}-\mathrm{N}$ poisoning should not be anticipated from the spring water sources as the concentration of both the $\mathrm{NO}_{3}^{-}-\mathrm{N}$ and $\mathrm{NO}_{2}^{-}-\mathrm{N}$ are below the critical value of $10 \mathrm{mg} / \ell$ above which it may be dangerous for pregnant women and bottle-fed babies to drink water from Isinuka springs.

Isinuka River water and Ferry Point Cottage spring are freshwater bodies. In addition, Ferry Point Cottage spring showed no evidence of salt intrusion from the Indian Ocean as might be expected in view of its proximity to the sea. The water was unpolluted from a chemical perspective and may be safe for drinking and domestic use without treatment.

Visitors to Isinuka springs and others believe in the healing power of the spring water, its bottom sediment and the pungent gaseous emissions from the alleged abandoned and dried-up spring site in Isinuka Village. They use these to cure and to suppress their ailments and consider them to be more economical, safe and dependable than the orthodox and traditional medicines. It will, therefore, be of interest to investigate the effectiveness of the water and characteristics of the sediment and gaseous emission from the springs.

\section{Acknowledgement}

The authors gratefully acknowledge the financial support of the National Research Foundation(NRF) and the University of Transkei Research Grant Committee (URC).

\section{References}

BUSH D and MAYER M (1982) A case of infantile methemoglobinemia in South Dakota. J. Environ. Health 44 (6) 310-311.

COMLY HH (1945) Cyanosis in infants by nitrates in well water. Am. Med. Assoc. J. 129 (2) 112-116.

COTRUVO JA (1988) Drinking water standards and risk assessment. Regulat. Toxicol. Pharmacol. 8 (3) 288.

DALLAS HF AND DAY JA (1993) The Effect of Water Quality Variables on River and Ecosystem. Water Research Commission Report No TT $61 / 93$.
DWAF (1986) Management of Water Resources of the Republic of South Africa. Department of Water Affairs and Forestry, Pretoria.

DWAF (1993) South Africa Water Quality Guidelines for Domestic, Recreational, and Agricultural Use Vols. 1-3. Department of Water Affairs and Forestry.

DWAF (1997) White Paper on a National Water Policy for South Africa. Department of Water Affairs and Forestry, Pretoria.

EEC (1980) European Economic Community Standards for Parameters Concerning Substances Undesirable in Excess Amounts. J. Eur. Comm. 23 L229/11-L229/23.

EPA (1994) Drinking Water Regulations and Health Advisories. Office of Water, US Environmental Protection Agency, Washington DC.

FANIRAN JA, ADELEKE BB and ODERINDE RA (1994) Forcados Terminal Integrated Projects: Baseline Ecological Studies. Commissioned by Shell Petroleum Development Company of Nigeria(SPDC).

HAMMER MJ (1975) Water and Wastewater Technology. John Wiley and Sons Inc. New York, London, Sydney, Toronto.

HWC (1987) Guidelines for Canadian Drinking Water Quality. Health and Welfare, Canada.

JAGALS P, GRABOW WOK and WILLIAMS E (1997) The effects of supplied water quality on human health in an urban development with limited basic subsistence facilities. Water SA 23 (4) 373-378.

KELTER PB, GRUNDMAN J, HAGE DS and CARR JD (1997) A discussion of water pollution in the US and Mexico with High School laboratory activities for analysis of lead, anthrazine and nitrate. Chem. Educ. 74 (12) 1413-1418.

KEMPSTER PL, VAN VLIET HR and KUHN A (1997) The need for guidelines to bridge the gap between ideal drinking-water quality and that quality which is practicably available and acceptable. Water SA 23 (2) 163-167.

QUILBELL G, VAN VLIET H and VAN DER MERWE W (1997) Characterising cause-and effect relationships in support of catchment water qualitymanagement. Water SA 23 (3) 193-198.

SABS (1984) Specification for Water for Domestic Supplies. South Africa Bureau of Standards SABS(241), Pretoria.

SDWA (1996) American Safe Drinking Water Act in Public Water Systems. USA.

SKONG DA and LEARY JJ (1992) Principles of Instrumental Analysis. Saunders, New York.

STANDARD METHODS (1975) Standard Methods for the Examination of Water and Wastewater (14 ${ }^{\text {th }}$ edn.). American Public Health Association (APHA), Washington DC.

SWLR (1995) South African Law Review - You and Your Water Right. Department of Water Affairs and Forestry (DWAF), Pretoria

USEPA (1996) Quality Criteria for Water. EPA 440/5-86-001, US Environmental Protection Agency, Washington DC, USA.

VAN DER MERWE CR (1962) Soil Groups and Sub-groups of South Africa. Div. of Chem. Services, Dept. of Agriculture (RSA).

WHO (1984) Guidelines for Drinking Water Quality - Health Criteria and other Supporting Information. World Health Organisation, Geneva, Switzerland.

WHO (1993) Guidelines for Drinking Water Quality. World Health Organisation, Geneva, Switzerland. 